\title{
Environmental Law
}

\section{The effect of the European Convention on Human Rights on UK environment law}

\author{
by Justine Thornton and Stephen Tromans
}

The European Convention on Human Rights (ECHR) does not refer to the environment in its list of rights and freedoms. The European Court of Human Rights, the body responsible for interpreting the convention is, however, creatively interpreting rights that are listed in it to counter environmental damage. The extent of its creativity is of particular relevance as the UK prepares to incorporate the convention into UK law.

\section{RESPECT FOR HOME AND PRIVATE LIFE}

The right to respect for private and family life (art. 8) features most prominently in the developing jurisprudence on environmental protection. This may be due in part to the fact that the first time that harm to the environment was found to be a breach of the convention it was found to be a breach of art. 8. In Lopez Ostra $v$ Spain (joined applications 9278/81 and 9415/81 35 D\&R (1984) 30) a treatment plant for liquid and solid tannery wastes, which was situated a few metres from the applicant's home in Lorca in Spain, released fumes, smells and contamination which caused health problems and nuisance to the local people.

The court was prepared to allow that environmental pollution could affect home and family life:

'severe environmental pollution may affect individuals' well-being and prevent them from enjoying their homes in such a way as to affect their private and family life adversely, without, however, seriously endangering their health.'

The case of Lopez Ostra followed a line of earlier cases concerned with noise pollution. In the case of Rayner (Powell \& Rayner v United Kingdom 172 Eur Ct Hr (ser A) para. 41 (1990)), the applicant complained about noise from aircraft at London Heathrow Airport. The commission considered that noise nuisance can undoubtedly affect the physical well-being of a person and thereby interfere with his private life. As well as physical well-being, the court has also shown itself prepared to protect a certain quality of life.

The scope of art. 8 has recently been extended to include failure by a government to release details of pollution risks. In Guerra $v$ Italy (application $116 / 1196 / 735 / 932)$ the court was prepared to find that a failure by the Italian authorities to provide the local population with information about the risk factor from a nearby chemical factory interfered with the right to a home life.

Article 8 is however limited in the extent to which it can protect the environment. The wording of its second paragraph allows a state to interfere with the right to a home life in the interests of national security, public safety or the economic well-being of the country. The court has, in practice, tended to grant states a considerable amount of leeway if an issue of national security or public safety arises.

Further, the only two cases where the applicant has succeeded in establishing a breach of the convention have, on their facts, been extreme (Lopez Ostra v Spain and Guerra v Italy).

\section{RIGHT TO LIFE (ART. 2)}

Protection of the environment is directly related to the right to life (art. 2), in that to survive people need uncontaminated food to eat, clean water to drink, healthy air to breathe and somewhere to shelter. So far, however, the court has adopted a restrictive interpretation of the right to life, confining it to the conditions under which a state inflicts capital punishment, rather than extending it to protecting the quality of life.

\section{PEACEFUL ENJOYMENT OF POSSESSIONS}

The commission has considered that every kind of negative effect caused by environmental nuisances could indirectly amount to interference with the right to peaceful possession of property (art. 1, protocol No. 1, 1952). In Rayner the court accepted that noise could affect the value of the property and therefore amount to a partial taking of the property.

\section{RIGHT TO A FAIR TRIAL}

The right to a fair trial (art. 6) provides procedural rather than substantive protection. It does not require a particular result to be achieved, but it does regulate how the result is arrived at.

In Zander $v$ Sweden (Ser A, No. 279B (1993)) the court found a breach of art 6 because the applicant was unable to challenge the decision of a licensing authority to allow a company to dump waste on a tip without requiring the company concerned to take precautionary measures to avoid pollution of the applicant's drinking water.

Conversely, those who object to proposed action by the state to protect the environment also have the right to challenge such action before a tribunal. In Fredin $v$ Sweden (ECHR, Ser A, No. 192 (1991)) a landowner was unable to obtain judicial review of the authority's decision to prohibit him from extracting gravel. The court held that this amounted to a breach of art. 6 .

\section{FREEDOM OF EXPRESSION}

Public access to information on the environment is recognised as a key aspect of environmental protection. Article 10 (1) includes the right to receive information. This has been interpreted as a negative obligation on the state not to impede an individual from obtaining access to information requested. It has not however extended to a positive obligation on the state to provide information. This was confirmed in the recent case of Guerra v Italy. 


\section{'ENVIRONMENTAL RIGHTS' UNDER THE CONVENTION}

It is not possible to conclude that any 'environmental rights' have been established under the convention. The court and commission have accepted that the enjoyment of a certain quality of environment is part of enjoying the right to a family life and to peaceful enjoyment of possession. Yet only two applications have succeeded and these were, on their facts, extreme. The protection granted by the substantive rights is limited by the wide margin of discretion allowed to states as to how they choose to protect the environment. The emerging jurisprudence shows a piecemeal and untidy picture. This is perhaps because protection of the environment is being squeezed into the ambit of other substantive rights. It may be, in this respect, that the procedural rights, such as a right to a tribunal and to access to information, offer a better opportunity for protecting the environment.

\section{EFFECT OF THE ECHR ON UK ENVIRONMENTAL LAW}

The effects of incorporation of the convention on UK environmental law are difficult to predict. Much will depend on the ingenuity of lawyers' arguments in future cases and on judicial willingness to respond to what may well be an opportunity for a more creative approach to the law.

\section{Effects on procedure}

Access to justice and the procedural safeguards under UK law are as developed, if not more so, than the convention jurisprudence. The convention could however provide a useful backdrop for defendants, who are adopting increasingly sophisticated techniques in order to avoid a guilty plea, particularly as the number of prosecutions for environmental offences increases - as do the fines and adverse publicity associated with any prosecution.

In 1996 the European Court of Human Rights held the use of evidence obtained from Ernest Saunders (in $R v$ Saunders, Case 175/78 [1979], ECR 1129; CMR 8558) under DTI investigatory powers in subsequent criminal proceedings against him was contrary to the requirement of fair procedure under art. 6 of the convention. The applicant in Hertfordshire County
Council ex parte Green Environmental Industries Ltd and John Moyneham (CA (Civil Division) 30 July 1997) referred both to the Saunders case and art. 6. The case concerned the powers of the Environment Agency to request specified information under s. 71 of the Environmental Protection Act 1990. The applicant claimed that this section could not be lawfully invoked for the purposes of conducting investigations into alleged criminal conduct. As the case was decided in the UK courts the court properly in the circumstances - decided the issue on EC case law. It did not however object to the reference to art. 6 .

\section{Expansion of litigants}

Environmental issues are becoming an increasingly important part of management buy-outs, takeovers and corporate acquisitions and disposals. Although it is usual for analysis of the convention to focus on the rights given to individuals it is also the case that companies may make complaints under the convention. At present organisations and companies make comparatively few complaints. It is likely however that the number will increase once the convention is part of UK law.

Substantial rights have been given to companies under art. 1 of the first protocol and the right to peaceful possession of property. Industry may challenge decisions taken to protect the environment if these interfere with its possessions. Although not successful the case of Fredin indicates the potential application of the right. The applicant had obtained a permit to exhibit a gravel pit. An amendment to the law on nature conservation subsequently authorised the revocation of such permits. The applicant claimed this interfered with his right to peaceful enjoyment of his possessions.

Industry has also made use of art. 6 and the right to a fair hearing. In Bentham v Netherlands (97 EUR CTHR (Ser A (1985)) the applicant applied for a licence to operate an installation for the delivery of liquid petroleum gas and motor vehicles. The licence was necessary to construct/operate installations that might be a source of danger or disturbance to surroundings. The licence was granted by local authorities but was then quashed by a national decree. The applicant alleged that the dispute had not been heard by an independent and impartial tribunal. The court found art. 6 to be applicable. As already mentioned, Green Environmental Industries Ltd made use of art. 6 in their challenge to the right of the Environment Agency, to require it to provide specified information as part of an investigation into criminal behaviour.

\section{Effects on the substantive law}

It is possible to highlight several examples of where the rights to life and to a family and home life may in their present scope influence UK law. Of most significance to environmental law is the potential for expanding the scope of the nuisance action; the predominant method of environmental control at common law

Under English law it is not possible to make a claim in private nuisance with absence of an exclusive interest in the land affected by the nuisance. A licensee or occupier has no right to sue. This restriction may well be a breach of the right to a family life under art. 8. A licensee or occupier cån, after all, still have a home life.

Under UK law, most of the activities which once constituted public nuisances at common law are now statutory nuisances, a regime which provides a faster and cheaper remedy. Light pollution is not covered under the current statutory nuisance provisions yet light can interfere with home life. In the circumstances a person might rely on the right to a home life in challenging any planning decision permitting, for example, the erection of floodlights that shine in neighbouring houses.

More interesting however is the potential for expansion of the rights to life and to a family life and the tentative willingness of the European Court and the commission to do so.

\section{RECOGNITION}

The court recognises for its part that in today's society the protection of the environment is an increasingly important consideration (European Court of Human Rights 1991)

In its judgments on art. 8 the European Court has accepted that it may be interpreted not only as requiring a state to abstain from interfering with the individual's right to a home life, but also as including a positive obligation on the state to take positive measures to protect 
these rights. This approach could require states to take positive measures to maintain or improve environmental quality to meet a standard compatible with respect for the right to private life.

The European Court has not yet gone so far as to require a state to undertake positive obligations. This may be due to the sensitivity of the court to the charge that it acts as a supranational body, which has made it wary of interfering in decisions made by states. The UK courts will not be under the same restraints and may adopt a more robust approach.

There are also indications of a willingness by the European Court to expand the scope to the right to life. In Association $X_{V}$ United Kingdom (application 7154/75 14 Eur Comn HR D\&R, 31, 32 [1979]), parents whose children had died or been severely injured as a result of vaccinations claimed that the British authorities had unjustifiably jeopardised the children's lives by not providing information on the risks of vaccination. The commission accepted that the state was obliged not only to refrain from taking life intentionally but also to take adequate steps to safeguard it. However, as the state had not intended the injuries, and adequate measures had been taken, the complaint was declared to be illfounded.

In Guerra v Italy Walsh J was of the view that art. 2 guarantees the protection of the bodily integrity of the applicants. Jambrek J saw the protection of health and physical integrity as being equally closely associated with the right to life as to the right to respect for private and family life. He was prepared to accept that the withholding of information about environmental risks could come within art. 2 and that the court's case law on art. 2 should start evolving in this respect.

Over time, an expansion of art. 2 may have the biggest effect on UK environmental law. The right to life could be invoked by workers claiming exposure to the risk of industrial accidents as a result of poor management systems or the use of chemicals whose toxicity is unknown. Similar principles will apply to risks from chronic pollution, as for example asthma caused by traffic, or exposure to asbestos dust or to pesticides.

\section{CONCLUSION}

There is certainly scope for the ECHR to affect the development of UK environmental law particularly with respect to creative uses of the right to life and the right to family and home life. The convention is also likely to perform the more nebulous task of keeping enforcement authorities on their toes in the light of the added weapon in the hands of plaintiffs.

Incorporation will not, however, resolve a number of underlying issues that make environmental litigation particularly difficult. These include valuing loss to the environment and linking the complex scientific explanations for pollution to legal concepts of causation.

\section{Justine Thornton \& Stephen Tromans Simmons \& Simmons}

\section{Human Rights}

\section{Protection from discrimination: the European dimension}

\section{by Geoffrey Bindman}

The government's intention in the Human Rights Act 1998 is to make the rights protected by the European Human Rights Convention (EHRC) enforceable in domestic law. This is to be achieved by requiring public authorities to act in conformity with those rights and by giving the courts the right to determine whether or not they have done so. Judges must interpret both common law and statute law to give effect as far as possible to those rights. Only when a statute cannot be so interpreted will the courts be powerless to implement the convention. In that situation their role will be limited to making a declaration of incompatibility, which it will be for Parliament to correct. The domestic courts will not be bound by decisions of the European Court of Human Rights but they must take them into account.
The rights to be incorporated are only those set out in the convention. Surprisingly, these do not include the right not to suffer discrimination on racial or other arbitrary grounds. The convention provides in art. 14 merely as follows:

'The enjoyment of the rights and freedoms set forth in this convention shall be secured without discrimination on any ground such as sex, race, colour, language, religion, political or other opinion, national or social origin, association with a national minority, birth or other status."

Yutaka Arai, in an article in Amicus Curiae November 1998, at p. 6, explained how art. 14 has been interpreted by the European Court and Commission of Human Rights and demonstrated that they have given it a broad interpretation wherever possible, even to the extent of holding that a breach of art. 14 can occur where no violation of a substantive right has been proved. Nevertheless the absence of a substantive right to be free of discrimination in the convention is a severe restriction on its effectiveness as a safeguard against unfair discrimination.

The limited protection against discrimination in the convention reflects a general lack of concern about discrimination in Europe as a whole at the time when the convention was introduced in 1950. Notwithstanding the recent terrible experience of the Holocaust, politicians failed to recognise any role for the law in the protection of ethnic minorities. Such groups were often perceived in terms of nationality or citizenship, and there was a long-standing assumption that discrimination on those grounds was legitimate and a proper exercise of national sovereignty. 